\section{Effect of Short-Term Starvation on Serum Metabolites, Antioxidant Enzymes and Endogenous Reserves of Rainbow Trout, Oncorhynchus mykiss}

\author{
Tayfun Karataş \\ Health Services Vocational School, Agri Ibrahim Cecen University, Agri 04100, Turkey
}
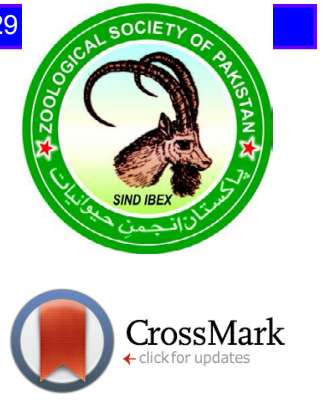

\begin{abstract}
A B S T R A C T
This study was conducted to investigate the effects of starvation for 8 days on the serum metabolites and antioxidant enzymes, thiobarbituric acid reacting substance levels, endogenous reserves in liver and muscle tissues of rainbow trout (Oncorhynchus mykiss). Eight-days of fasting caused a significant decrease in glucose, total protein, triglyceride, cholesterol, high-density lipoprotein and low-density lipoprotein levels as well as protein and lipid reserves in liver and muscle tissue of fish $(\mathrm{p}<0.05)$. The fasting period had no significant effect on the hepatic thiobarbituric acid reactive substances (TBARS), but, it caused a significant decrease in the hepatic catalase and glutathione peroxidase $(\mathrm{p}<0.05)$. In muscle tissue, the TBARS levels were significantly decreased $(\mathrm{p}<0.05)$. Whereas, antioxidant enzyme activities remained unchanged $(p>0.05)$. The results obtained from this study showed that the short-term starvation leads to significant changes on serum metabolites, antioxidant enyzme activities and endogenous reserves of rainbow trout.
\end{abstract}

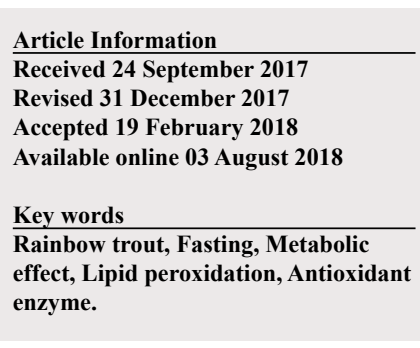

\section{INTRODUCTION}

$\mathrm{M}$ any fish species have the ability to tolerate starvation because they cannot adequately meet their nutritional needs as well as breeding and migration (Hinch et al., 2005; Miller et al., 2009). The use of energy in fish varies depending on particularly adverse environmental conditions and food insufficiency (Salem et al., 2007). if the fish cannot feed adequately, activate their endogenous reserves to maintain their vital processes such as brain function, regulation of respiration and mineral balance (Furne et al., 2012). Endogenous reserves are generally regarded as a reflection of the metabolic responses of fish to environmental conditions and malnutrition (Wang et al., 2006; Furne et al., 2012). These are also due to different age, size and being natural or cultural fish (Navarro and Gutie'rrez, 1995). In some fish, liver glycogen is first used during fasting (Hung et al., 1997; Figueiredo-Garutti et al., 2002; Meto'n et al., 2003). During the first stages of a starvation, the hydrolysis of glycogen has a significant effect in the regulation of blood glucose homeostasis that is to deliver glucose to blood after glycogenolysis from glycogen in liver at short-term starvation (Furne et al., 2012). In other words, glucose homeostasis is the

\footnotetext{
Corresponding author: tkaratas025@gmail.com 0030-9923/2018/0005-1723 \$9.00/0

Copyright 2018 Zoological Society of Pakistan

This work is presented at the International Biochemistry Congress
}

regulation of the concentration of glucose. In addition, fat reserves are used as a last metabolit, if the starvation is increased a great degree. However, studies made on some species of fish have reported that fish use energy from the muscle protein of the last active reserve if the available energy sources are not sufficient (Navarro and Gutie' rrez, 1995). Conversely, studies on some species have reported that liver glycogen deposits try to regulate reduced protein and lipid levels for glyconeogenesis (Sheridan and Mommsen, 1991; Navarro and Gutie'rrez, 1995; Gillis and Ballantyne, 1996; Furne et al., 2012).

The fish are generally exposed to two types of starvation. These are short term and long-term starvation. Short-term nutritional starvation accelerates aging, injury, toxicity of chemicals and diseases in fish (Pascual et al., 2003; Najafi et al., 2014). Also, short-term nutritional starvation causes the reduction of antioxidant deposits in the organs of organisms and increased production of free radicals in liver (Pascual et al., 2003; Furne et al., 2009). This process can be attributed to increase of reactive oxygen species generated by starvation and leading to oxidative stresses (Robinson et al., 1997). Oxidative stress is a process related to the inadequate removal of reactive oxygen species from where it is present (Sies, 1986). Therefore, organisms are protected from reactive oxygen species by means of different defense mechanisms (Pascual et al., 2003). The defense mechanisms are catalase (CAT), superoxide dismutase (SOD), glutathione peroxidase (GPx) and glutathione reductase (GR). Antioxidants with low molecular weight such as glutathione, $\mathrm{E}$ and $\mathrm{C}$ 
vitamins act by enzymatic defense mechanisms (Furne et al., 2009, 2012).

The aim of this study was to determine alterations in levels of serum metabolit (Glucose, total protein, triglyceride, cholesterol, HDL, LDL), antioxidant enzymes activities such as catalase (CAT), superoxide dismutase (SOD), glutathione peroxidase (GPx) and glutathione reductase (GR), as well as thiobarbituric acid reacting substances (TBARS) levels, a lipid peroxidation product, in the liver and muscle tissues and endogenous reserves such as protein and lipid of rainbow trout.

\section{MATERIALS AND METHODS}

\section{Experimental animals}

120 rainbow trout (Oncorhynchus mykiss) average weight $170 \mathrm{~g}$ were obtained from the fish farm, $41 \mathrm{~km}$ away from Ağr province. A group of 40 fish were divided into four groups, each of ten. One was fed twice a day (Control), while the others were starved for a day (T1), 2 days (T2) and 8 days (T3). This experiment was repeated three times. The temperature, dissolved oxygen and $\mathrm{pH}$ of the water in which the fish was about $12 \pm 0.8^{\circ} \mathrm{C}, 10.3$ and 7.5 , respectively.

\section{Biochemical analysis of blood, liver and muscle}

Blood samples were taken from the caudal veins of the fish with the help of a $5 \mathrm{cc}$ syringe and transferred to anticoagulation tuples and used for the estimation levels of glucose, total protein, triglyceride, cholesterol, highdensity lipoprotein (HDL) and low-density lipoprotein (LDL) according to Karataş and Kocaman (2014). Briefly, the blood samples taken from fish were centrifuged at $3000 \mathrm{rpm}$ for 10 minutes and the serum was separated. Glucose, total protein, triglyceride, cholesterol, HDL, LDL and triglyceride were analyzed with autoanalyzer Cobas C6000 using commercial biochemical kits. The samples of liver and muscle tissues were placed in liquid nitrogen and stored at $-80^{\circ} \mathrm{C}$ until analyzed according to the method of Furne et al. (2012).
Measurement of TBARS and antioxidant enzyme activities TBARS levels, a lipid peroxidation product, as well as antioxidant enzymes activities such as CAT (EC 1.11.1.6), SOD (EC 1.15.1.1), GPx (EC 1.11.1.9) and GR (EC 1.8.1.7) were analysed. Antioxidant enzyme activities in liver and muscle tissues (SOD, CAT, GPx and GR and TBARS levels were measured according to the methods defined by Furne et al. (2012).

\section{Statistical analysis}

Data were analyzed by SPSS 20.0 for Windows, using one-way analyses of variance (ANOVA). Differences were determined by using Duncan's multiple range tests. $\mathrm{P}<0.05$ was considered statistically significant.

\section{RESULTS}

The data obtained from this study and the statistical analyzes of these data are summarized in Tables I, II and III. According to these results, levels of blood glucose, triglyceride, cholesterol, HDL and LDL of T3 group were significantly decreased compared to other groups $(\mathrm{p}<0.05)$ (Table I). Starvation had no significant effect on blood total protein levels and liver lipid reserves of all the three starvation groups when compared to control group (Table II). However, liver protein reserves of T3 group $(p<0.05)$ were significantly reduced when compared to other groups. Protein and lipid reserves in muscle tissue decreased significantly only in the T3 group $(p<0.05)$ compared to the other groups (Table II). In liver tissues of groups (Table III), although there were slight fluctuations in thiobarbituric acid reactive substances (TBARS) levels of all the three starvation groups compared to control group ( $p>0.05)$, significant decreases in levels of CAT and GPx of T3 group were observed $(\mathrm{p}<0.05)$. No significant difference levels of SOD and GR were observed ( $p>0.05$ ). In muscle tissues, while TBARS level in T3 group were significantly decreased $(\mathrm{p}<0.05)$, SOD, CAT, GPx and GR levels were increased. However, these increases were not statistically significant $(\mathrm{p}>0.05)$ (Table III).

Table I.- Changes in the serum metabolites of rainbow trout during short-term fasting.

\begin{tabular}{|c|c|c|c|c|}
\hline Metabolites $\left(\mathrm{mg} \mathrm{dL}^{-1}\right)$ & Control & T1 & $\mathbf{T 2}$ & T3 \\
\hline Glucose & $93.6 \pm 2.65^{\mathrm{a}}$ & $91.2 \pm 2.41^{\mathrm{a}}$ & $79.3 \pm 1.20^{\mathrm{a}}$ & $56.3 \pm 2.58^{b}$ \\
\hline Total protein & $3.60 \pm 0.25^{\mathrm{a}}$ & $3.58 \pm 0.32^{\mathrm{a}}$ & $3.54 \pm 0.34^{\mathrm{a}}$ & $3.49 \pm 0.27^{\mathrm{a}}$ \\
\hline Total cholesterol & $319.1 \pm 4.13^{\mathrm{a}}$ & $319.8 \pm 5.17^{\mathrm{a}}$ & $314.5 \pm 7.10^{\mathrm{a}}$ & $210.2 \pm 3.24^{\mathrm{b}}$ \\
\hline HDL & $101.4 \pm 3.90^{\mathrm{a}}$ & $100.4 \pm 3.80^{\mathrm{a}}$ & $94.2 \pm 3.70^{\mathrm{a}}$ & $73.6 \pm 2.13^{b}$ \\
\hline LDL & $180 \pm 7.9^{\mathrm{a}}$ & $182 \pm 3.08^{\mathrm{a}}$ & $191.6 \pm 8.56^{\mathrm{a}}$ & $90.3 \pm 10.40^{b}$ \\
\hline Triglycerides & $395.6 \pm 14.3^{\mathrm{a}}$ & $391.6 \pm 18.54^{\mathrm{a}}$ & $297.3 \pm 12.23^{\mathrm{a}}$ & $201.4 \pm 9.51^{b}$ \\
\hline
\end{tabular}

The results were given as mean and standard deviation. Different letters indicate differences between groups. One was fed twice a day (Control), a day (T1), 2 days (T2) and 8 days (T3) of starvation. 
Table II.- Alterations in levels of protein and lipid in liver and muscle tissues of rainbow trout during short-term fasting.

\begin{tabular}{llcccc}
\hline \% wet weight & Tissues & Control & T1 & T2 & T3 \\
\hline Protein & Liver & $11.34 \pm 1.76^{\mathrm{a}}$ & $11.41 \pm 2.14^{\mathrm{a}}$ & $10.96 \pm 2.25^{\mathrm{a}}$ & $8.75 \pm 0.35^{\mathrm{b}}$ \\
Protein & Muscle & $7.15 \pm 0.47^{\mathrm{a}}$ & $6.94 \pm 0.55^{\mathrm{a}}$ & $6.53 \pm 0.51^{\mathrm{a}}$ & $3.27 \pm 0.19^{\mathrm{b}}$ \\
Lipid & Liver & $4.86 \pm 0.26^{\mathrm{a}}$ & $4.83 \pm 0.39^{\mathrm{a}}$ & $4.45 \pm 0.41^{\mathrm{a}}$ & $4.16 \pm 0.37^{\mathrm{a}}$ \\
Lipid & Muscle & $18.91 \pm 2.21^{\mathrm{a}}$ & $18.63 \pm 2.19^{\mathrm{a}}$ & $14.71 \pm 0.89^{\mathrm{a}}$ & $8.75 \pm 2.14^{\mathrm{b}}$ \\
\hline
\end{tabular}

The results were given as mean and standard deviation. Different letters indicate differences between groups. One was fed twice a day (Control), a day (T1), 2 days (T2) and 8 days (T3) of starvation.

Table III.- Alterations in thiobarbituric acid reactive substances (TBARS) levels and the activities of catalase (CAT) glutathione reductase (GR) glutathione peroxidase (GPx) and superoxide dismutase (SOD) in liver and muscle of rainbow trout during short-term fasting.

\begin{tabular}{|c|c|c|c|c|}
\hline $\begin{array}{l}\text { Lipid peroxidation and } \\
\text { antioxidant enzymes }\end{array}$ & Control & T1 & T2 & T3 \\
\hline \multicolumn{5}{|l|}{ Liver } \\
\hline TBARS (nmol g-1 tissue) & $40.3 \pm 2.57^{\mathrm{a}}$ & $41.2 \pm 2.47^{\mathrm{a}}$ & $44.3 \pm 2.03^{\mathrm{a}}$ & $48.7 \pm 2.04^{\mathrm{a}}$ \\
\hline CAT (U mg ${ }^{-1}$ protein) & $358.1 \pm 10.3^{\mathrm{a}}$ & $355.4 \pm 8.71^{\mathrm{a}}$ & $341.5 \pm 8.17^{\mathrm{a}}$ & $337.2 \pm 5.49^{b}$ \\
\hline SOD (U mg ${ }^{-1}$ protein) & $635.3 \pm 20.4^{\mathrm{a}}$ & $630.1 \pm 6.53^{a}$ & $614.2 \pm 6.15^{\mathrm{ab}}$ & $588.0 \pm 7.6^{\mathrm{a}}$ \\
\hline GPx (mU mg ${ }^{-1}$ protein) & $483.2 \pm 19.6^{\mathrm{a}}$ & $485.1 \pm 16.2^{\mathrm{a}}$ & $455 \pm 30.4^{\mathrm{ab}}$ & $403.7 \pm 41.4^{b}$ \\
\hline GR (mU mg ${ }^{-1}$ protein) & $15.4 \pm 2.86^{\mathrm{a}}$ & $15.8 \pm 3.05^{\mathrm{a}}$ & $14.7 \pm 1.90^{\mathrm{a}}$ & $14.3 \pm 2.11^{\mathrm{a}}$ \\
\hline \multicolumn{5}{|l|}{ Muscle } \\
\hline TBARS (nmol g-1 tissue) & $80.4 \pm 5.8^{\mathrm{a}}$ & $80.1 \pm 4.7^{\text {a }}$ & $77.3 \pm 4.6^{\mathrm{a}}$ & $60.5 \pm 1.2^{\mathrm{b}}$ \\
\hline CAT ( $\mathrm{U} \mathrm{mg}^{-1}$ protein) & $0.034 \pm 0.02^{\mathrm{a}}$ & $0.036 \pm 0.10^{\mathrm{a}}$ & $0.046 \pm 0.02^{\mathrm{a}}$ & $0.058 \pm 0.02^{\mathrm{a}}$ \\
\hline $\mathrm{SOD}\left(\mathrm{U} \mathrm{mg}^{-1}\right.$ protein $)$ & $62.4 \pm 1.8^{\mathrm{a}}$ & $63.1 \pm 3.1^{\mathrm{a}}$ & $68.7 \pm 2.27^{\mathrm{a}}$ & $71.5 \pm 1.3^{\mathrm{a}}$ \\
\hline GPx (mU mg-1 protein) & $139.2 \pm 10.3^{\mathrm{a}}$ & $141.2 \pm 10.3^{\mathrm{a}}$ & $149.8 \pm 11.5^{\mathrm{a}}$ & $155.2 \pm 20.8^{\mathrm{a}}$ \\
\hline GR (mU mg ${ }^{-1}$ protein) & $4.21 \pm 1.5^{\mathrm{a}}$ & $4.60 \pm 1.02^{\mathrm{a}}$ & $4.90 \pm 0.71^{\mathrm{a}}$ & $5.12 \pm 1.9^{\mathrm{a}}$ \\
\hline
\end{tabular}

The results were given as mean and standard deviation. Different letters indicate differences between groups. One was fed twice a day (Control), a day (T1), 2 days (T2) and 8 days (T3) of starvation.

\section{DISCUSSION}

The physiological process is considered as a reflection on fish alterations in environmental conditions such as temperature, hardness, $\mathrm{pH}$ etc. and harmful substances including oxidative stress and fasting stress. Fasting stress in fish can be affected by many factors such as fasting time, species of fish, and metabolism. These factors may be one of the most important reasons for the change in serum metabolite levels of fish. Fasting can be used to show species-specific differences in the metabolism and regulation of blood glucose (Kim et al., 2014). In this study, glucose level decreased significantly in the T3 group when compared to the other groups. Kim et al. (2014) reported a decrease in plasma glucose levels of the salmonids such as brook trout, S. fontinalis (Heming and Paleczny, 1987), Chinook salmon, O. tshawytscha (Barton et al., 1988) and Rainbow trout, O. mykiss (Farbridge and Leatherland, 1992). On the other hand, there are studies indicating an increase in plasma glucose levels of fish such as, jundia, Rhamdia quelen (Barcellos et al., 2010), Dicentrarchus labrax, European seabass (Chatzifotis et al., 2011), Senegalese sole, Solea senegalensis (Costas et al., 2011) or red porgy (Caruso et al., 2010), Antarctic fish, Notothenia coriiceps (Stepanowska et al., 2006). But, no significant increases were reported (Kim et al., 2014; Shabana et al., 2017). These results were consistent with previous studies (Heming and Paleczny, 1987; Barton et al., 1988; Farbridge and Leatherland, 1992). Kim et al. (2014) reported fasting in many fish species including European eel (Dave et al., 1975), brook trout (Heming and Paleczny, 1987) and Senegal sole (Costas et al., 2011) caused significant reductions in plasma protein concentration levels. In this study, protein levels in liver 
and muscle tissues of T3 group was significantly reduced when compared to other groups. Decrease in the protein reserves of the fish during fasting period may be associated with converting energy of protein via gluconeogenesis. Cho (2009) reported that protein levels can be a good indicator in determining the severity of fasting. Another reason for the decrease in protein levels in the liver and muscle tissues may be due to either reduction in ribosomes or slowing of protein synthesis depending on starvation. These results were consistent with studies made by Dave et al. (1975), Heming and Paleczny (1987), Costas et al. (2011) and Cho (2009).

Cholesterol is needed in the synthesis of sexual hormones and for cell membranes (Kulkarni and Barad, 2015). In this study, level of total cholesterol of T3 group was statistically decreased significant compared to other groups. Furne et al. (2012) reported that the rainbow trout exposed to 10-day hunger had significant reductions in total cholesterol levels. In another study, Black and Skinner (1986) reported that there were no significant effects on levels of serum cholesterol of the rainbow trout of fasting. Results obtained in this study groups were similar with results of Black and Skinner (1986) and Furne et al. (2012).

Triglycerides, responsible for providing the energy and nutrient needs of the cells, are known deposits of fat in the body (Kulkarni and Barad, 2015). In this study, there was a statistically significant decrease in the triglyceride ratio of the T3 group. This condition may be associated with decrease in the phospholipids of the T3 group since blood serum in the fish is an important lipid carrier. These results were consistent with those of Friedrich and Stepanowska (2001) and Kulkarni and Barad (2015).

Lipoproteins are transported into the body fluid in the form of complexes with proteins of water-insoluble lipids. Lipids, triglycerides, cholesterol esters, free cholesterol and phospholipids contain one or several different protein molecules. Lipoproteins have two important groups: LDL and HDL. HDL is rich in phospholipids and cholesterol. While HDL is carried from the peripheral tissues to liver to lipid metabolites, LDL carries lipid components from the tissues around the liver (Zech et al., 1986; Karatas and Kocaman, 2012; Karatas and Kocaman, 2014). In this study, levels of HDL and LDL of T3 group were significantly decreased compared to the other groups. Decreases in HDL and LDL levels may be associated with a decrease in total cholesterol levels. These results were consistent with the results of Kulkarni and Barad (2015).

The use of hepatic lipids as an energy source during fasting varies according to species and lipid reserve tissue (Godin and Wohaieb, 1988). The energy that the body needs is usually provided by activating other reserves, such as carbohydrates (Kim et al., 2014). In this study, lipid levels were significantly decreased in T3 group. The decrease in muscle lipid levels in fish may be indicative of the use of lipid reserves for energy purposes or during fasting of fish may be associated with decreased lipid mobilization between the liver and perivascular tissues. In this sense, decreases in HDL and LDL levels may be responsible for slowing or decreasing of lipid synthesis.

It was determined that the environmental conditions altered the level of lipid peroxidation and antioxidant enzymes (Drozd et al., 2014; Panicz et al., 2017). The formation of oxidative stress in fish is usually associated with an increase in the level of lipid peroxidation by the effect of starvation and starvation stress (Furne et al., 2009). Some authors working on different fish species reported that starvation and starvation stress increased the level of lipid peroxidation in liver of fish such as rainbow trout (Oncorhynchus mykiss), gilthead seabream (S. aurata) and common dentex (D. dentex) (Hidalgo et al., 2002; Pascual et al., 2003; Morales et al., 2004). It was reported that carp applied diets increased lipid peroxidation and decreased antioxidant level (Stepanowska and Sawicka, 2006). Regarding the activities of liver antioxidant enzymes of rainbow trout, in this study, there was a decrease in antioxidant enzymes such as CAT and GPx due to the increase in fasting time. These decreases are due to a decrease in enzyme synthesis substrates, possibly may cause an increase in lipid peroxidation levels. These findings were consistent with the results of Furne et al. (2009) and Godin and Wohaieb (1988). Blom et al. (2000) and Morales et al. (2004) have been reported that starvation is caused by the decrease in GR enzyme activity of rainbow trout and common dentex. Pascual et al. (2003) reported a reduction in CAT and GPx levels while SOD and GR levels were elevated in fasting conditions. Morales et al. (2004) reported that there is a significant effect of deprivation on SOD, CAT and GPx levels. Therefore, the liver is probably considered one of the best parameters to demonstrate antioxidant defenses in organisms (Chance et al., 1979; Davies, 1991; Wilhelm-Filho et al., 1993). In contrast to liver tissue, level of TBARS in muscle tissue of T3 group was significantly reduced. Decreased TBARS levels are likely due to the increase in activities. Another reason for the decrease in TBARS levels may be due to a reduction in energy reserves in muscle tissue. Because, the fish in fasting state may activate the energy reserves in muscle tissue and thus may decrease the effects of lipid peroxidation (TBARS).

\section{CONCLUSION}

Results obtained in this study showed that short- 
term fasting was caused significant changes on the serum metabolit levels, endogenous reserves such as protein and lipid and antioxidant enzymes activities of rainbow trout. Therefore, serum or plasma metabolits, liver and muscle tissues may be important in determining the effects on different fish species of starvation. Further studies are needed to determine the effects of starvation on fish physiology.

\section{ACKNOWLEDGEMENTS}

The author thanks to Dr. Naim Uzun from biochemistry department, Faculty of Pharmacy, Ağrı İbrahim Çeçen University, for his contributions in this study.

\section{Statement of conflict of interest}

No conflict of interest was reported by the authors.

\section{REFERENCES}

Barcellos, L.J.G., Marqueze, A., Trapp, M., Quevedo, R.M. and Ferreira, D., 2010. The effects of fasting on cortisol, blood glucose and liver and muscle glycogen in adult jundia, Rhamdia quelen. Aquaculture, 300: 231-236. https://doi. org/10.1016/j.aquaculture.2010.01.013

Barton, B.A., Schreck, C.B. and Fowler, L.G., 1988. Fasting and diet content affect stress-induced changes in plasma glucose and cortisol in juvenile Chinook salmon. Prog. Fish Cult., 50: 16-22. https:// doi.org/10.1577/1548-8640(1988)050<0016:FAD $\mathrm{CAS}>2.3 . \mathrm{CO} ; 2$

Black, D. and Skinner, E.R., 1986. Features of the lipid transport system of fish as demonsuated by studies on starvation in the rainbow trout. J. comp. Physiol. B., 156: 497-502. https://doi.org/10.1007/ BF00691035

Blom, S., Andersson, T.B. and Fo“rlin, L., 2000. Effects of food deprivation and handling stress on head kidney 17a-hydroxyprogesterone 21-hydroxylase activity, plasma cortisol and the activities of liver detoxification enzymes in rainbow trout. Aquat. Toxicol., 48: 265-274. https://doi.org/10.1016/ S0166-445X(99)00031-4

Caruso, G., Maricchiolo, G., Micale, V., Genovese, L., Caruso, R. and Denaro, M.G., 2010. Physiological responses to starvation in the European eel (Anguilla anguilla): Effects on haematological, biochemical, non-specific immune parameters and skin structures. Fish Physiol. Biochem., 36: 71-83. https://doi.org/10.1007/s10695-008-9290-6

Chance, B., Sies, H. and Boveris, A., 1979.
Hydroperoxide metabolism in mammaliam organs. Physiol. Rev., 59: 527-605. https://doi.org/10.1152/ physrev.1979.59.3.527

Chatzifotis, S, Papadaki, M, Despoti, S, Roufidou, C, Antonopoulou, E., 2011. Effect of starvation and re-feeding on reproductive indices, body weight, plasma metabolites and oxidative enzymes of sea bass (Dicentrarchus labrax). Aquaculture, 316: 53-59. https://doi.org/10.1016/j. aquaculture.2011.02.044

Cho, S.H., 2009. Effect of fasting and refeeding on growth and blood chemistry in juvenile olive flounder, Paralichthys olivaceus. J. Aquacul., 22: 11-15.

Costas, B., Aragao, C., Ruiz-Jarabo, I., Vargas-Chacoff, L., Arjona, F.J., Dinis, M.T., Mancera, J.M. and Conceicao, L.E.C., 2011. Feed deprivation in Senegalese sole (Solea senegalensis Kaup, 1858) juveniles: Effects on blood plasma metabolites and free amino acid levels. Fish Physiol. Biochem., 37: 495-504. https://doi.org/10.1007/s10695-0109451-2

Dave, G., Johansson-Sjo"beck, M.L., Larsson, A., Lewander, K. and Lidman, U., 1975. Effects of cortisol on the fatty acid composition of the total blood plasma lipids in the European eel, Anguilla anguilla L. Comp. Biochem. Physiol. A., 64: 37-40. https://doi.org/10.1016/0300-9629(79)90427-4

Davies, K.J.A., 1991. Oxidative damage and repair: Chemical, biological and medical aspects. Pergamon Press, Oxford.

Drozd, R., Panicz, R., Jankowiak, D., Hofsoe, P., Drozd, A. and Sadowski, J., 2014. Antoxidant enzymes in the liver and gills of Tinca tinca from various water bodies. J. appl. Ichthyol., 30: 2-6. https://doi. org/10.1111/jai.12420

Farbridge, K.J. and Leatherland, J.F., 1992. Plasma growth hormone levels in fed and fasted rainbow trout (Oncorhynchus mykiss) are decreased following handling stress. Fish Physiol. Biochem., 10: 67-73. https://doi.org/10.1007/BF00004655

Friedrich, M. and Stepanowska, K., 2001. Effects of starvation on nutritive value of carp (Cyprinus carpio L.) and selected biochemical components of its blood. Acta Ichtyol. Pisc., 31: 29-36. https://doi. org/10.3750/AIP2001.31.2.03

Figueiredo-Garutti, M.L., Navarro, I., Capilla, E., Souza, R., Moraes, G., Gutie'rrez, J. and VicentiniPaulinoe, M.L., 2002. Metabolic changes in Brycoon cephalus (Teleostei, Characidae) during post-feeding and fasting. Comp Biochem. Physiol. A., 132: 467-476. https://doi.org/10.1016/S1095- 
6433(02)00094-6

Furne,' M., Garci'a-Gallego, M., Hidalgo, M.C., Morales, A.E., Domezain, A., Domezain, J. and Sanz, A., 2009. Oxidative stress parameters during starvation and refeeding periods in Adriatic sturgeon (Acipenser naccarii) and rainbow trout (Oncorhynchus mykiss). Aquacult. Nutr., 15: 587-595. https://doi.org/10.1111/j.13652095.2008.00626.x

Furne,' M., Morales, A.E., Trenzado, C.E., Garcı'aGallego, M., Hidalgo, M.C., Domezain, A. and Sanz, A., 2012. The metabolic effects of prolonged starvation and refeeding in sturgeon and rainbow trout. J. comp. Physiol. B., 182: 63-76. https://doi. org/10.1007/s00360-011-0596-9

Gillis, T.E. and Ballantyne, J.S., 1996. The effects of starvation on plasma free amino acid and glucose concentrations in lake sturgeon Acipenser fulvescens. J. Fish Biol., 49: 1306-1316. https://doi. org/10.1111/j.1095-8649.1996.tb01797.x

Godin, D.V. and Wohaieb, S.A., 1988. Nutritional deficiency, starvation, and tissue antioxidant status. Free Radic. Biol. Med., 5: 165-176. https://doi. org/10.1016/0891-5849(88)90079-2

Heming, T.A. and Paleczny, E.J., 1987. Compositional changes in skin mucus and blood serum during starvation of trout. Aquaculture, 66: 265-273. https://doi.org/10.1016/0044-8486(87)90112-8

Hidalgo, M.C., Expo'sito, A., Palma, J.M. and De la Higuera, M., 2002. Oxidative stress generated by dietary Zn-deficiency; studies in rainbow trout (Oncorhynchus mykiss). Int. J. Biochem. Cell Biol., 34: 183-193. https://doi.org/10.1016/S13572725(01)00105-4

Hinch, S.G, Cooke, S.J., Healey, M.C. and Farrel, A.P., 2005. Behavioural physiology of fish migrations: salmon as a model approach. Fish Physiol., 24: 239-295. https://doi.org/10.1016/S15465098(05)24007-4

Hung, S.S.O., Liu, W., Li, H., Storebakken, T. and Cui, Y., 1997. Effect of starvation on some morphological and biochemical parameters in white sturgeon, Acipenser transmontanus. Aquaculture, 151: 357-363. https://doi.org/10.1016/S00448486(96)01506-2

Karataş, T. and Kocaman, E.M., 2012. Comparison of paraoxonase activity, malondialdehyde and highdensity lipoprotein levels in cultivated normal and albino rainbow trout reared in the same conditions. Kafkas Univ. Vet. Fak. Derg., 18: 87-90.

Karataş, T. and Kocaman, E.M., 2014. Susceptibility to oxidative damage in wild and cultured brook trouts
(Salvelinus fontinalis, Mitchill, 1815). Int. J. Fish. aquat. Stud., 2: 180-183.

Karataş, T., Kocaman, E.M. and Atamanalp, M., 2014. The comparison of total cholesterol and cholesterol types of cultured rainbow (Oncorhynchus mykiss, Walbaum, 1972) and brook trouts (Salvelinus fontinalis, Mitchill, 1815) cultivated under the same water conditions. Int. J. Fish. Aquacult., 6: 16-19. https://doi.org/10.5897/IJFA11.051

Kim, J.H., Jeong, M.H., Jun, J.C. and Kim, L.T., 2014. Changes in hematological, biochemical and nonspecific 1mmune parameters of olive flounder, Paralichthys olivaceus, following starvation. Asian-Australas. J. Anim. Sci., 27: 1360-1367. https://doi.org/10.5713/ajas.2014.14110

Kulkarni, R.S. and Barad, V.S., 2015. Effect of starvation on haematological and serum biochemical changes in the fresh water fish, Notopterus notopterus (pallas). Int. J. Innov. Stud. Aquat. Biol. Fish., 1: 24-29.

Meto'n, I., Ferna'ndez, F. and Baanante, I.V., 2003. Short- and long-term effects of refeeding on key enzyme activities in glico'lisisgluconeogenesis in the liver of gilthead seabream (Sparus aurata). Aquaculture, 225: 99-107. https://doi.org/10.1016/ S0044-8486(03)00281-3

Miller, K.M., Schulze, A.D., Ginther, N., Li, S., Patterson, D.A., Farrell, A.P. and Hinch, S.G., 2009. Salmon spawning migration: metabolic shifts and environmental triggers. Comp. Biochem. Physiol., 4: 75-89. https://doi.org/10.1016/j.cbd.2008.11.002

Morales, A.E., Pe'rez-Jime'nez, A., Hidalgo, M.C., Abella'n, E. and Cardenete, G., 2004. Oxidative stress and antioxidant defences alter prolonged starvation in Dentex dentex liver. Comp. Biochem. Physiol., 139: 153-161.

Najafi, A.., Salati, A.P., Yavari, V. and Asadi. F., 2014. Effects of short-term starvation and re-feeding on antioxidant defense status in Mesopotamichthys sharpeyi (Günther, 1874) fingerlings. Int. J. aqua. Biol., 2: 246-252.

Navarro, I. and Gutie'rrez. J., 1995. Fasting and starvation. In: Biochemistry and molecular biology of fishes, metabolic biochemistry, Vol. 4 (eds. P.W. Hochachka and T.P. Mommsen). Elsevier, Amsterdam, pp. 393-434.

Panicz, R., Drozd, R., Drozd, A. and Nędzarek, A., 2017. Species and sex-specific variation in antioxidant status of tench (Tinca tinca), wels catfish (Silurus glanis) and sterlet (Acipenser ruthenus) reared in cage culture. Acta Ichthyol. Piscat., 47: 213-223. https://doi.org/10.3750/AIEP/02093 
Pascual, P., Pedrajas, J.R., Toribio, F., Lo'pez-Barea, J. and Peinado, J., 2003. Effect of food deprivation on oxidative stress biomarkers in fish (Sparus aurata). Chem. Biol. Interact., 145: 191-199. https://doi. org/10.1016/S0009-2797(03)00002-4

Robinson, M.K., Rustum, R.R., Chambers, E.A., Rounds, J.D., Wilmore, D.W. and Jacobs, D.O., 1997. Starvation enhances hepatic free radical release following endotoxemia. J. Surg. Res., 69: 325-330. https://doi.org/10.1006/jsre.1997.5062

Shabana, Ehsan, F. and Hasnain, S., 2017. Association of Gly482Ser varient of PPARGC1 $\alpha$ gene with diabetes in Pakistani Population. Pakistan J. Zool., 49: 1933-1936. http://dx.doi.org/10.17582/journal. pjz/2017.49.5.sc7

Salem, M., Silverstein, J., Rexroad, C.E. and Yao, J., 2007. Effect of starvation on global gene expression and proteolysis in rainbow trout (Oncorhynchus mykiss). BMC Genomics, 8: 328-343. https://doi. org/10.1186/1471-2164-8-328

Sheridan, M.A. and Mommsen, T.P., 1991. Effects of nutritional state on in vivo lipid and carbohydrate metabolism of coho salmon Oncorhynchus kisutch. Gen. comp. Endocrinol., 81: 473-483. https://doi. org/10.1016/0016-6480(91)90175-6

Sies, H., 1986. Biochemistry of oxidative stress. Angew. Chem. Int. Ed. Engl., 25: 1058-1071. https://doi. org/10.1002/anie.198610581

Stepanowska, K. and Sawicka, A., 2006. The effect of feeding method on body weight gains, concentrations of selected components in the blood, and peroxidation processes of carp, Cyprinus carpio L. Acta Ichtyol. Piscat., 36: 25-29. https:// doi.org/10.3750/AIP2006.36.1.04

Stepanowska, K., Nędzarek, A. and RakusaSuszczewski, S., 2006. Effects of starvation on the biochemical composition of blood and body tissue in the Antarctic fish, Notothenia coriiceps (Richardson, 1844) and excreted metabolic products. Polar Biosci., 20: 46-54.

Wang, T., Hung, C.C.Y. and Randall, D.J., 2006. The comparative physiology of food deprivation: from feast to famine. Annu. Rev. Physiol., 68: 223-251. https://doi.org/10.1146/annurev. physiol.68.040104.105739

Wilhelm-Filho, D.W., Giulivi, C. and Boveris, A., 1993. Antioxidant defenses in marine fish-I. Teleosts. Comp. Biochem. Physiol., 106: 409-413.

Zech, L.A., Boston, R.C. and Foster, D.M., 1986. The methodology of compartmental modeling as applied to the investigation of lipoprotein metabolism. Methods Enzymol., 129: 366-384. https://doi.org/10.1016/0076-6879(86)29080-1 